\title{
Learner Behavior in e-Learning as a Multicriteria Attribute based on Perspective of Flow Experience
}

\author{
Dadang Syarif Sihabudin Sahid \\ Department of Information Technology \\ Politeknik Caltex Riau, Pekanbaru, Indonesia
}

\begin{abstract}
Flow experience describe psychological condition in the form of optimal experience of an activity. Flow shows an interconnection, interest, and pleasure toward an activity, thus enable user to fully participate in the activity. In e-learning activity, flow provides positive experience of a learning process. This condition is essential in user's ability to achieve high performance. Therefore, it is important to identify user's flow experience during his interaction with e-learning. This information can be used as reference of how e-learning model provide response that in accordance with user's psychological condition. Assessment of psychological experience based on flow theory have been conducted in many studies, particulary based on experience sampling method. However, these survey methods require high effort thus they are inefficient. The previous studies in this topic only covers conventional learning, with face-to-face interaction. In e-learning, particulary those that use adaptive context aware e-learning approach, flow experience can be assessed by conducting inference based on learning behavior parameters of learners during interaction with e-learning. However, there is no study that provide relation among learner's learning behavior in e-learning with parameters of flow experience. Therefore, this study tested hypotheses aimed to obtain relation between learning behavior and flow experience. Hypotheses model constructed by involving technology acceptance model (TAM), expectation confirmation model, and flow experience as learning psychological condition. Learning behavior as a multicriteria attribute was represented by actual usage in form of intensity of using e-learning. Meanwhile, perceived balance of skill and challenge as representation of flow experience was selected as main variable in the proposed hypotheses. The result showed that these variables had positive relation with each other.
\end{abstract}

Keywords-Flow experience; learning behavior; multicriteria attribute; TAM; e-learning

\section{INTRODUCTION}

Along with the development of ubiquitous and pervasive computing, e-learning technology adapts with users' requirement and behavior [1]. E-learning, which initially follows teacher centered learning design, has developed into student centered learning at present. This means that elearning has been developed with emphasize to adaptive aspects and user personalization. In the past, e-learning was a rigid system with one procedural line in providing knowledge to learners. Meanwhile, e-learning nowadays provides adaptive learning to satisfy learners' requirement, situation, and behavior. One way to achieve adaptive e-learning is by developing context aware e-learning.

This research is sponsored by Ministry of Research, Technology, and Higher Education, Republic of Indonesia, 2020.
The implementation of context-aware in e-learning system motivates learners to be actively engaged in learning process. Context-aware e-learning provides adaptive learning that satisfies learners' requirement, situation, and behavior. This system is able to overcome important issues in e-learning implementation, which one of them is how e-learning system considers learners' psychological condition during interaction with the system.

As presented by Zhang and Cheng [2], the development of context aware e-learning personalization model with consideration of learners' psychological condition as context and reference to specific learning pattern is limited. Yet, Whitson and Consoli [3] stated that the learners' psychological condition plays important role in motivating learners in learning process.

The most common psychological conditions experienced by learners during learning is anxiety, boredom, and optimal. These three conditions follow the flow theory [4], that analyzes motivation, emotional, and cognitive condition of learners [5]. Flow state is proposed by Csikszentmihalyi [6], describing condition when learners' skills (experience, knowledge, cognitive skill) are proportional to the given challenges/problems. Meanwhile, anxiety occurs when learner's skills are lower than the level of given challenges/problems. In contrast, boredom occurs when learners skills are higher than the level of given challenges/problems.

Studies of psychological conditions identification based on flow theory generally conducted in conventional learning process as e-learning is not supported by context aware personalization technology. Studies of psychological experience assessment also often conducted via surveys and questionnaires [7] that spent long time and require high effort. However, as in conventional learning process, learning behavior in e-learning can assess learners' psychological condition during interaction by their behaviors and characteristic [8]. Learning behavior can be used to assess one person acceptance toward a technology, especially e-learning technology. Positive learning behavior will induce positive psychological experience shown by learner's active engagement toward e-learning. Hence, this study observed relation among learning behavior as multicriteria attribute, technology acceptance based on TAM variables, and flow experience components as a representation of learning psychological condition. This paper is organized as follows: Introduction (Section I), Literature Review (Section II), Hypotheses Development (Section III), Method (Section IV), 
Results and Discussion (Section V), and Conclusion (Section VI).

\section{LiteratURE REVIEW}

The literature review is focused on components related to technology acceptance model (TAM), flow experience, and learning intensity as representation of learning behavior. These components are perceived ease of use, perceived usefulness, attitude, intention, enjoyment, perceived control, skill-challenge balance, engagement and learning intensity.

\section{A. Perceived Ease of Use}

Perceived ease of use is a level of how much one person can trust an information technology to be able to easily used [9]. Intensity of use and interaction between user and system also can be considered as indicators of ease of use [10]. When a system is frequently used, it means that the system is easy to understand, operate, and implement. Perceived ease of use [11] is an individual trust level toward whether the technology can aid him in completing his task.

Based on the aforementioned explanation, ease of use of an information technology depended on individual trust level toward whether the system is easy to understand, operate, implement. Therefore, common indicators of perceived ease of use are: information technology is easy to understand, information technology is easy to implement, and information technology is easy to operate.

\section{B. Perceived Usefulness}

Perceived usefulness is defined as an individual trust level toward how the use of a subject benefits the user [9][10]. These benefits can be considered from various point of views [12], such as:

- Makes job easier

- Useful

- Increase productivity

- Enhance effectiveness

- Improve job performance

\section{Attitude}

Attitude toward e-learning is user evaluation, either positive or negative one, of e-learning use. This evaluation is related to favorable or unfavorable behavior toward e-learning use [13]. This attitude is an internal state that influenced individual thought of specific object, person, or activity. Attitude is a cognitive, affective, and behavior tendency that is studied to give positive or negative response toward specific object, situation, institution, concept, or person [14]. Attitude is a personal factor that contains positive evaluation or inner behavior of avoiding, resisting, or blocking an object [15].

\section{Intention}

Intention in TAM is a behavior tendency toward use of technology [9]. Intention is user psychic aspect that tends to pay attention of prefer the use of technology to meet his objective [16]. Intention to use can be defined as user intention to use or reuse a specific technology.
Intention to use can be assessed by at least two factors: Compatibility, which is a level where user perceives an innovation based on his value, past experience, and potential requirement; Ease of use, which is a level where user perceives a specific subject is easy to the implement or operate.

\section{E. Perceived Control}

Perceived control is a person ability to control an event, subject, technology or other conditions [17]. This condition is related with internal control of situation or belief to influence other person or the environment. A person with high perceived control tends to be highly motivated in meeting his objective, have potential and necessary skill to overcome a situation. In contrast, a person with low perceived control tends to have a passive attitude [18][19].

\section{F. Enjoyment}

In several literatures, enjoyment is often associated as pleasure, interest, comfort, and other positive feeling. In learning, enjoyment is something frequently conducted that relates to mastering a specific skill [6]. Enjoyment is a level where activity of using a technology brings pleasure to the user, apart from the value of the technology itself. Enjoyment can also be explained as a high comfort of a person during interaction with information technology. If perceived usefulness is regarded as external motivation, then perceived enjoyment is an internal motivation of information technology use [11].

\section{G. Learning Intensity}

Learning intensity in e-learning represents one person's behavior during interaction with e-learning (learning behavior). As with conventional learning, intensity of attending classes, intensity of doing assignments, activity of collaboration, and activity of exploration are indicators of whether one person engaged in learning. In e-learning situation, this learning behavior can be observed, noted, and explored from $\log$ files in server [20]. Several observed behaviors are: learning participation, learning duration, duration to complete assignments, and number of completed assignments. These are examples of exploration behavior of learning material.

\section{H. Balance of Skill and Challenge}

Balance of skill and challenge is often referred to assess flow psychology experience occurrence. Flow theory is firstly explained by Mihaly Csikszentmihalyi who use the word 'flow' to represent optimal experience of someone to be focused to his involvement in an activity [6]. An individual in flow condition is in state of high concentration so that there are no space for other thoughts or disturbance. Even though flow is constructed of various complex variables, skill and challenge are two of the most important variables [21][22].

\section{Student Engagement}

Student engagement is essential in learning process, particularly in e-learning. One of the challenges is building students' interest on learning. Engagement in learning will bring positive effect on student learning performance. Something noticeable such as student's behavior when 
accessing e-learning, but also something unnoticeable such as psychological condition. This condition related to persistence and consistency level of a student and his positive emotion during interaction with e-learning.

Fredricks et al. [23] states that engagement is a combination of three dimensions: behavioral, cognitive, and emotional. Behavioral engagement relates with students' behaviors observed during interaction in learning process, such as attendance, activeness in completing assignments, and participation in learning process [24]. Cognitive engagement generally includes mastering of skill, knowledge, idea [25], internal motivation to learn something, and ability to plan, supervise, and evaluate a specific learning. Emotional engagement relates with students' feeling and emotion during learning, such as excitement, boredom, anxious, sadness, and other emotions [26].

\section{HyPOTHESES DEVELOPMENT}

Hypotheses in this study was constructed by involving components of flow theory, extension of expectation confirmation model, and technology acceptance model (TAM) in learning with application of e-learning. Flow theory and TAM has interconnected components, for example component of perceived ease of use in TAM is interconnected with component of skill and challenge in flow theory. Other interconnected components are perceived usefulness, attitude, intention, and actual usage.

As stated in previous literature review, skill and challenge have positive effect on perceived ease of use and perceived usefulness. In TAM extension, skill-challenge is shows external variable of relevant skill and challenge [11]. Someone with adequate skill of prior knowledge and web experience, in addition to being able to overcome given challenge will bring positive influence on perceived ease of use and perceived of usefulness. Skill-challenge balance illustrates the occurrence of flow experience. Hence, the first, second, third and fourth hypotheses of this study were:

- H1: Skill and challenge balance brings positive influence on perceived ease of use.

- H2: Skill and challenge balance brings positive influence on perceived usefulness.

- H3: Skill and challenge balance brings positive influence on enjoyment.

- H4: Skill and challenge balance brings positive influence on perceived control.

Student with perceived ease of use can navigate e-learning use easily. Perception also affect perceived usefulness of elearning. This is a valid relation as explained by previous studies involving TAM model [9]. This also valid for relation of perceived usefulness, attitude, intention and actual usage.

As explained before in student engagement, learning intensity is a representation of user behavior during interaction with e-learning. This component is something that can be used to illustrate user characteristic when using e-learning. In TAM model, learning intensity can be observed as part of user actual usage when using e-learning, which can be observed and measured quantitatively. A person with perceived usefulness toward e-learning will have attitude that displays elearning has positive influence on learning. This attitude is followed with intention that yielded proper intensity when using e-learning. Based on this information, hypotheses fifth to ninth can be stated as:

- H5: Perceived ease of use bring positive influence on perceived usefulness.

- H6: Perceived usefulness bring positive influence on attitude.

- H7: Perceived ease of use bring positive influence on attitude.

- H8: Attitude bring positive influence on intention.

- H9: Attitude bring positive influence on actual usage.

Ming-Chi Lee study proves that there is a relation among flow parameters of enjoyment, concentration, and perceived control with attitude and intention [27]. From the previous relation, intention has an influence on actual usage that can be observed when user use e-learning persistently and consistently. This consistency is a mark of learning intensity. Therefore, the tenth, eleventh, and twelfth hypotheses can be stated as:

- H10: Enjoyment brings positive influence on attitude.

- H11: Perceived control brings positive influence on attitude.

- H12: Perceived control brings positive influence on intention.

These hypotheses create an outer model as displayed in Fig. 1.

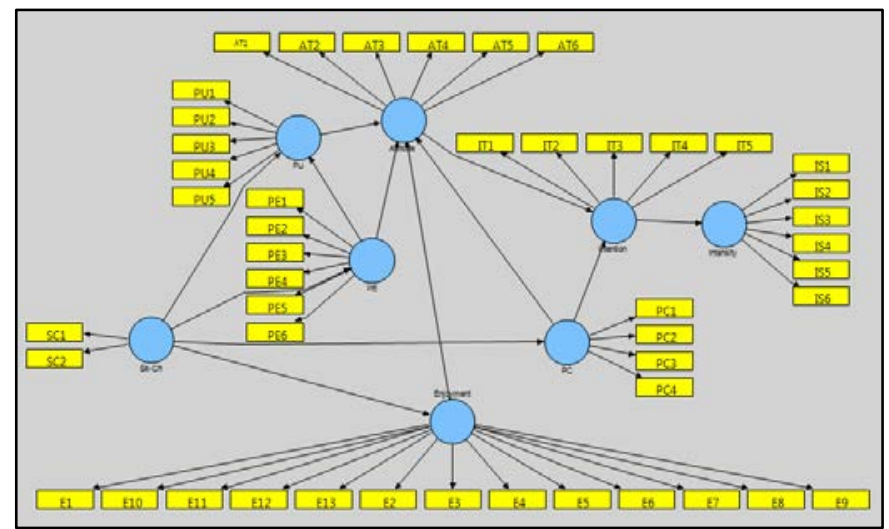

Fig. 1. Outer Model.

\section{METHOD}

This was an explanatory study that explained causal relation among study variables by testing hypotheses with survey method. This method is suitable for testing study hypotheses, whether it is a descriptive, comparative, or associative hypotheses. 


\section{A. Constructs and Indicators}

This study was approached with combination of flow theory and TAM components relating the use of e-learning. As illustrated in previous structure model, constructs and indicators of this study are shown at Table I.

TABLE I. CONSTRUCTS AND INDICATORS

\begin{tabular}{|c|c|c|}
\hline No. & Construct & Indicator \\
\hline 1. & $\begin{array}{l}\text { Perceived } \\
\text { Balance Skill- } \\
\text { Challenge }\end{array}$ & $\begin{array}{l}\text { SC1. Mastering of skill } \\
\text { SC2. Mastering of challenge }\end{array}$ \\
\hline 2. & $\begin{array}{l}\text { Perceived Ease } \\
\text { of Use (PE) }\end{array}$ & $\begin{array}{l}\text { PE1. Ease of use } \\
\text { PE2. Ease of study } \\
\text { PE3. Ease of navigation } \\
\text { PE4. Flexibility of use } \\
\text { PE5. Ease of finding material } \\
\text { PE6. Stability and continuity of use }\end{array}$ \\
\hline 3 & $\begin{array}{l}\text { Perceived } \\
\text { usefulness (PU) }\end{array}$ & $\begin{array}{l}\text { PU1. Ease of learning process } \\
\text { PU2. Effectiveness of learning } \\
\text { PU3. Skill improvement } \\
\text { PU4. Ease of learning activity } \\
\text { PU5. Benefit of learning }\end{array}$ \\
\hline 4 & $\begin{array}{l}\text { Learning } \\
\text { Intensity }\end{array}$ & $\begin{array}{l}\text { IS1. Frequency of use } \\
\text { IS2. Duration of use } \\
\text { IS3. Frequency of interest } \\
\text { IS4. Duration of interest } \\
\text { IS5. Frequency of study achievement } \\
\text { IS6. Duration of study achievement }\end{array}$ \\
\hline & Enjoyment & $\begin{array}{l}\text { E1. Awakening (Drowsy - Awake) } \\
\text { E2. Happiness (Sad - Happy) } \\
\text { E3. Excited (Gloomy - Excited) } \\
\text { E4. Strength (Weak - Strong) } \\
\text { E5. Activeness (Passive - Active) } \\
\text { E6. Individual relation (Lonely - Popular) } \\
\text { E7. Self-confidence (Timid - Confident) } \\
\text { E8. Involvement (Separated - Involved) } \\
\text { E9. Interest (Bored - Interested) } \\
\text { E10. Openness (Closed - Open) } \\
\text { E11. Clarity (Confused - Clear) } \\
\text { E12. Relaxation (Stressed - Relax) } \\
\text { E13. Competitiveness (Competitive - } \\
\text { Cooperative) }\end{array}$ \\
\hline & Intention & $\begin{array}{l}\text { IT1. Intention to use routinely } \\
\text { IT2. Intention to use as main medium for } \\
\text { learning } \\
\text { IT3. Intention to use as communication event } \\
\text { IT4. Intention to use as main medium of learning } \\
\text { material } \\
\text { IT5. Intention to use as main medium for practice }\end{array}$ \\
\hline & Attitude & $\begin{array}{l}\text { AT1. Using e-learning is good } \\
\text { AT2. Using e-learning is important } \\
\text { AT3. Using e-learning is interesting } \\
\text { AT4. Using e-learning is positive } \\
\text { AT5. Using e-learning is exciting } \\
\text { AT6. Using e-learning is good for educational } \\
\text { institution }\end{array}$ \\
\hline & $\begin{array}{l}\text { Perceived } \\
\text { Control }\end{array}$ & $\begin{array}{l}\text { PC1. Level of concentration } \\
\text { PC2. Level of awareness when using e-learning } \\
\text { PC3. Level of feeling when using e-learning } \\
\text { PC4. Level of controlling situation }\end{array}$ \\
\hline
\end{tabular}

\section{B. Data Collection}

In this study, data was collected by conducting survey and direct observation in the field. Data was collected by interview, review of learning environment, review of learning facilities, review of distribution and geographic condition of participants, and providing questionnaire for learners. Interview was performed on teachers, headmaster and event organizer, and learners.

The questionnaire was based on constructs and indicators as illustrated in outer and inner models. Each questionnaire contained questions with alternative answers in attitude scale 1 to 5, which translated as 'strongly disagree' and 'strongly agree' attitudes, respectively. Several questionnaires also express level of negative and positive feeling toward use of elearning.

The study objects were students of open high school in West Bandung Region, West Java. Open high school uses long distance learning model aided with information and communication technology. This model help disseminate and enlarge access for education for community limited with time, geographic environment, and socio-economic problems. The study population was 600 students, while the number of samples was 186 students of tenth, eleventh, and twelfth grade. The sample also selected by considering gender, employment, and distribution of geographic environment of study location.

\section{Model Evaluation}

The model was evaluated by observing variables of outer and inner models. Outer model was evaluated based on three criteria: convergent validity, discriminant validity, and reliability testing. Meanwhile, inner model was evaluated by using R-square analysis, path coefficient value, and observing the value of calculated t-value as reference of significance of construct variables relation.

Convergent validity with reflective indicator was assessed based on correlation between item score/component score and construct score, which was calculated with PLS. Reflective size is considered high if the correlation value is more than 0.70 to the calculated construct. Discriminant validity with reflective indicator was assessed based on cross loading of calculation with construct. If construct correlation with calculated item is larger than the size of other constructs, it means that latent construct predicts one block size better than the size of other blocks. Other methods used to find discriminant validity was comparison of square root of Average Variance Extracted (AVE) each construct with correlation value of one construct with the other (latent variable correlation). Reliability was evaluated by observing values of composite reliability and cronbach alpha. These value shows consistency of calculated indicators.

R-square value, path coefficient, and t-value of bootstrapping are commonly used to evaluate inner model. Interpretation of this value is similar with interpretation of conventional regression, which shows ability of independent variable to describe its dependent variable. Path coefficient is a standardized regression coefficient that shows direct effect of independent variable on a dependent variable inside the 
model. This coefficient shows direction (positive or negative) of an exogenous variable effect on endogenous variable. Meanwhile, t-value obtained from bootstrapping used to observe significance of resulting path coefficient. In this study, the t-value was compared with t-table with significance of $5 \%$.

\section{RESUlTS AND DisCUSSION}

Based on data developed with SMART-PLS 2 application, the general results of this study are displayed in Fig. 2 and Fig. 3.

\section{A. Outer Model Evaluation}

Outer model or calculated model was evaluated by variables of convergent validity, discriminant validity, and composite reliability. Convergent validity was evaluated by outer loadings value of all indicators in each construct. As can be seen in Table II and Table III, outer loading of all indicators were $>0.7$, which means that reflective indicator used in this study was valid.

Discriminant validity of reflective indicator can be observed in cross loading between indicator and its construct. Cross loading output of PLS algorithm is displayed in Table IV. Cross loadings output shows that correlation of each indicator with its construct was higher than other constructs, which means that latent constructs predicted indicator in its own group better than indicator in other groups.

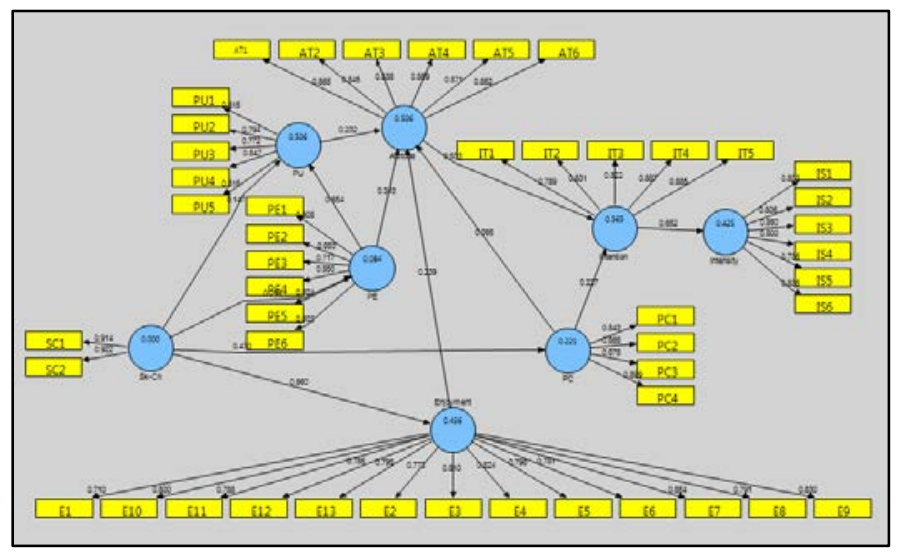

Fig. 2. Result of Developed Data using PLS.

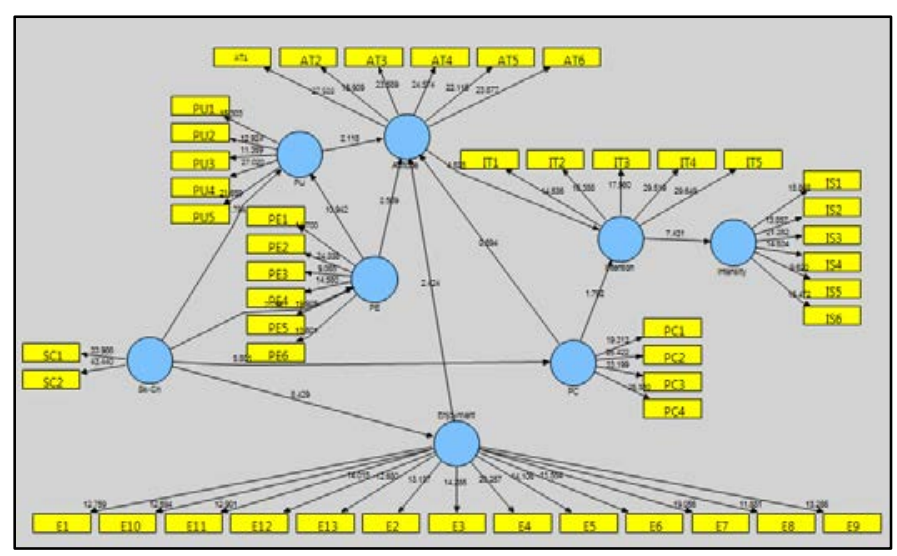

Fig. 3. Result of Developed Data using Bootstrapping.
TABLE II. OUTER LOADINGS (1)

\begin{tabular}{|l|l|l|l|l|}
\hline & Attitude & Enjoyment & Intensity & Intention \\
\hline AT1 & 0.865060 & & & \\
\hline AT2 & 0.845336 & & & \\
\hline AT3 & 0.837621 & & & \\
\hline AT4 & 0.858831 & & & \\
\hline AT5 & 0.870568 & & & \\
\hline AT6 & 0.852354 & & & \\
\hline E1 & & 0.709985 & & \\
\hline E10 & & 0.800327 & & \\
\hline E11 & & 0.788455 & & \\
\hline E12 & & 0.784546 & & \\
\hline E13 & & 0.795436 & & \\
\hline E2 & & 0.773233 & & \\
\hline E3 & & 0.809836 & & \\
\hline E4 & & 0.823621 & & \\
\hline E5 & & 0.798087 & & \\
\hline E6 & & 0.780855 & & \\
\hline E7 & & 0.853828 & & \\
\hline E8 & & 0.791450 & & \\
\hline E9 & & 0.829661 & & \\
\hline IS1 & & & 0.803432 & \\
\hline IS2 & & & 0.805628 & \\
\hline IS3 & & & 0.860103 & \\
\hline IS4 & & & 0.800075 & \\
\hline IS5 & & & 0.735610 & \\
\hline IS6 & & & 0.834604 & \\
\hline IT1 & & & & \\
\hline IT2 & & & & \\
\hline IT3 & & & & \\
\hline IT4 & & & & \\
\hline IT5 & & & & \\
\hline
\end{tabular}

TABLE III. OUTER LOADINGS (2)

\begin{tabular}{|l|l|l|l|l|}
\hline & PC & PE & PU & Sk-C \\
\hline PC1 & 0.842932 & & & \\
\hline PC2 & 0.866316 & & & \\
\hline PC3 & 0.877928 & & & \\
\hline PC4 & 0.898790 & & & \\
\hline PE1 & & 0.808248 & & \\
\hline PE2 & & 0.853019 & & \\
\hline PE3 & & 0.717279 & & \\
\hline PE4 & & 0.850064 & & \\
\hline PE5 & & 0.823625 & & \\
\hline PE6 & & 0.801512 & & \\
\hline PU1 & & & 0.815296 & \\
\hline PU2 & & & 0.793783 & \\
\hline PU3 & & & 0.771812 & \\
\hline PU4 & & & 0.847220 & \\
\hline PU5 & & & 0.816217 & \\
\hline SC1 & & & & 0.913872 \\
\hline SC2 & & & & 0.922269 \\
\hline
\end{tabular}


TABLE IV. CROSS LOADINGS

\begin{tabular}{|c|c|c|c|c|c|c|c|c|}
\hline & $\begin{array}{l}\text { Atti } \\
\text { tude }\end{array}$ & $\begin{array}{l}\text { Enjoy } \\
\text { ment }\end{array}$ & $\begin{array}{l}\text { Inten } \\
\text { sity }\end{array}$ & $\begin{array}{l}\text { Inten } \\
\text { tion }\end{array}$ & PC & $\mathbf{P E}$ & PU & $\begin{array}{l}\text { Sk- } \\
\text { Ch }\end{array}$ \\
\hline AT1 & 0.9 & 0.5 & 0.7 & 0.7 & 0.3 & 0.6 & 0.5 & 0.4 \\
\hline AT2 & 0.8 & 0.5 & 0.6 & 0.6 & 0.3 & 0.5 & 0.6 & 0.3 \\
\hline AT3 & 0.8 & 0.4 & 0.7 & 0.6 & 0.4 & 0.6 & 0.5 & 0.3 \\
\hline AT4 & 0.9 & 0.5 & 0.6 & 0.6 & 0.4 & 0.6 & 0.5 & 0.4 \\
\hline AT5 & 0.9 & 0.4 & 0.7 & 0.7 & 0.4 & 0.6 & 0.5 & 0.3 \\
\hline AT6 & 0.9 & 0.4 & 0.6 & 0.6 & 0.3 & 0.4 & 0.5 & 0.3 \\
\hline E1 & 0.4 & 0.7 & 0.4 & 0.4 & 0.5 & 0.4 & 0.2 & 0.5 \\
\hline E10 & 0.4 & 0.8 & 0.5 & 0.4 & 0.4 & 0.3 & 0.3 & 0.5 \\
\hline E11 & 0.4 & 0.8 & 0.4 & 0.3 & 0.4 & 0.4 & 0.3 & 0.5 \\
\hline E12 & 0.3 & 0.8 & 0.3 & 0.4 & 0.5 & 0.3 & 0.4 & 0.6 \\
\hline E13 & 0.4 & 0.8 & 0.4 & 0.4 & 0.4 & 0.4 & 0.4 & 0.5 \\
\hline E2 & 0.4 & 0.8 & 0.4 & 0.5 & 0.5 & 0.3 & 0.3 & 0.6 \\
\hline E3 & 0.4 & 0.8 & 0.3 & 0.3 & 0.4 & 0.3 & 0.2 & 0.5 \\
\hline E4 & 0.4 & 0.8 & 0.5 & 0.4 & 0.5 & 0.4 & 0.4 & 0.5 \\
\hline E5 & 0.4 & 0.8 & 0.4 & 0.4 & 0.5 & 0.4 & 0.4 & 0.6 \\
\hline E6 & 0.5 & 0.8 & 0.4 & 0.4 & 0.4 & 0.4 & 0.4 & 0.4 \\
\hline E7 & 0.5 & 0.9 & 0.4 & 0.4 & 0.5 & 0.4 & 0.4 & 0.5 \\
\hline E8 & 0.5 & 0.8 & 0.4 & 0.4 & 0.5 & 0.4 & 0.4 & 0.5 \\
\hline E9 & 0.4 & 0.8 & 0.4 & 0.4 & 0.4 & 0.3 & 0.4 & 0.5 \\
\hline IS1 & 0.6 & 0.4 & 0.8 & 0.5 & 0.3 & 0.5 & 0.4 & 0.3 \\
\hline IS2 & 0.5 & 0.3 & 0.8 & 0.5 & 0.2 & 0.5 & 0.4 & 0.2 \\
\hline IS3 & 0.7 & 0.4 & 0.9 & 0.6 & 0.4 & 0.6 & 0.5 & 0.3 \\
\hline IS4 & 0.6 & 0.3 & 0.8 & 0.5 & 0.2 & 0.5 & 0.4 & 0.2 \\
\hline IS5 & 0.5 & 0.5 & 0.7 & 0.5 & 0.3 & 0.5 & 0.5 & 0.2 \\
\hline IS6 & 0.7 & 0.5 & 0.8 & 0.6 & 0.3 & 0.6 & 0.6 & 0.3 \\
\hline IT1 & 0.5 & 0.4 & 0.6 & 0.8 & 0.4 & 0.5 & 0.4 & 0.4 \\
\hline IT2 & 0.6 & 0.4 & 0.5 & 0.8 & 0.4 & 0.5 & 0.3 & 0.4 \\
\hline IT3 & 0.6 & 0.4 & 0.5 & 0.8 & 0.4 & 0.5 & 0.3 & 0.3 \\
\hline IT4 & 0.7 & 0.4 & 0.6 & 0.9 & 0.4 & 0.5 & 0.4 & 0.4 \\
\hline IT5 & 0.7 & 0.5 & 0.6 & 0.9 & 0.4 & 0.5 & 0.4 & 0.4 \\
\hline PC1 & 0.2 & 0.5 & 0.2 & 0.4 & 0.8 & 0.2 & 0.2 & 0.4 \\
\hline PC2 & 0.3 & 0.5 & 0.3 & 0.4 & 0.9 & 0.2 & 0.2 & 0.4 \\
\hline PC3 & 0.4 & 0.5 & 0.4 & 0.5 & 0.9 & 0.3 & 0.3 & 0.4 \\
\hline PC4 & 0.4 & 0.5 & 0.4 & 0.4 & 0.9 & 0.4 & 0.3 & 0.4 \\
\hline PE1 & 0.6 & 0.3 & 0.5 & 0.4 & 0.3 & 0.8 & 0.6 & 0.2 \\
\hline PE2 & 0.5 & 0.3 & 0.5 & 0.5 & 0.2 & 0.9 & 0.6 & 0.2 \\
\hline PE3 & 0.5 & 0.3 & 0.5 & 0.5 & 0.3 & 0.7 & 0.5 & 0.2 \\
\hline PE4 & 0.5 & 0.5 & 0.5 & 0.4 & 0.3 & 0.9 & 0.6 & 0.3 \\
\hline PE5 & 0.5 & 0.4 & 0.5 & 0.5 & 0.3 & 0.8 & 0.6 & 0.3 \\
\hline PE6 & 0.5 & 0.4 & 0.5 & 0.4 & 0.2 & 0.8 & 0.5 & 0.2 \\
\hline PU1 & 0.5 & 0.4 & 0.5 & 0.4 & 0.2 & 0.5 & 0.8 & 0.3 \\
\hline PU2 & 0.5 & 0.3 & 0.4 & 0.3 & 0.2 & 0.5 & 0.8 & 0.3 \\
\hline PU3 & 0.5 & 0.3 & 0.5 & 0.4 & 0.3 & 0.5 & 0.8 & 0.3 \\
\hline PU4 & 0.5 & 0.3 & 0.5 & 0.4 & 0.2 & 0.7 & 0.8 & 0.2 \\
\hline PU5 & 0.5 & 0.4 & 0.5 & 0.4 & 0.3 & 0.6 & 0.8 & 0.3 \\
\hline SC1 & 0.4 & 0.6 & 0.3 & 0.4 & 0.4 & 0.3 & 0.3 & 0.9 \\
\hline SC2 & 0.3 & 0.6 & 0.3 & 0.4 & 0.5 & 0.3 & 0.3 & 0.9 \\
\hline
\end{tabular}

Other variables that can be used to evaluate discriminant validity is by comparison square root of AVE for each construct with correlation of one construct with others (Latent Variable Correlation).

Discriminant validity value is considered adequate if the square root of AVE for each construct is higher than latent variable correlation value. Output of AVE and latent variable correlation from PLS Algorithm are shown in Table V and Table VI. Based on comparison of both tables, the square root of AVE for each construct was higher than correlation of one construct with others.

Evaluation of construct reliability can be conducted based on two variables, composite reliability and croncbach alpha of indicator group that assess the construct. Construct is considered reliable if the composite reliability value and cronbach alpha are larger than 0.7. Output of composite reliability and cronbach alpha are displayed in Table VII.

TABLE V. AVE VALUE

\begin{tabular}{|l|l|l|}
\hline & AVE & AVE Square root \\
\hline Attitude & 0.731086 & 0.855036 \\
\hline Enjoyment & 0.633615 & 0.795999 \\
\hline Intensity & 0.652021 & 0.807478 \\
\hline Intention & 0.711746 & 0.843650 \\
\hline PC & 0.759905 & 0.871725 \\
\hline PE & 0.656464 & 0.810225 \\
\hline PU & 0.654897 & 0.809257 \\
\hline Sk-Ch & 0.842871 & 0.918080 \\
\hline
\end{tabular}

TABLE VI. LATENT VARIABLE CORRELATION

\begin{tabular}{|l|l|l|l|l|l|l|l|l|}
\hline & $\begin{array}{l}\text { Atti } \\
\text { tude }\end{array}$ & $\begin{array}{l}\text { Enjoy } \\
\text { ment }\end{array}$ & $\begin{array}{l}\text { Inten } \\
\text { sity }\end{array}$ & $\begin{array}{l}\text { Inten } \\
\text { tion }\end{array}$ & PC & PE & PU & $\begin{array}{l}\text { Sk- } \\
\text { Ch }\end{array}$ \\
\hline Attitude & 1 & & & & & & & \\
\hline Enjoyment & 0.5 & 1 & & & & & & \\
\hline Intensity & 0.7 & 0.5 & 1 & & & & & \\
\hline Intention & 0.7 & 0.5 & 0.7 & 1 & & & & \\
\hline PC & 0.4 & 0.6 & 0.4 & 0.5 & 1 & & & \\
\hline PE & 0.6 & 0.4 & 0.6 & 0.6 & 0.4 & 1 & & \\
\hline PU & 0.6 & 0.4 & 0.6 & 0.5 & 0.3 & 0.7 & 1 & \\
\hline Sk-Ch & 0.4 & 0.7 & 0.3 & 0.4 & 0.5 & 0.3 & 0.3 & 1 \\
\hline
\end{tabular}

TABLE VII. COMPOSITE RELIABILITY AND CRONBACHS ALPHA

\begin{tabular}{|l|l|l|}
\hline & Composite Reliability & Cronbachs Alpha \\
\hline Attitude & 0.942227 & 0.926444 \\
\hline Enjoyment & 0.957345 & 0.951605 \\
\hline Intensity & 0.918149 & 0.892857 \\
\hline Intention & 0.92493 & 0.898253 \\
\hline PC & 0.926757 & 0.894898 \\
\hline PE & 0.919547 & 0.89453 \\
\hline PU & 0.904573 & 0.868169 \\
\hline Sk-Ch & 0.914735 & 0.813687 \\
\hline
\end{tabular}


As can be seen in Table VII, the composite reliability value and cronbach alpha for each construct was larger than 0.70 , which means that each construct was considered reliable.

\section{B. Inner Model Evaluation}

Inner model or structure model can be evaluated based on $\mathrm{R}$-square, path coefficient, and t-value. R-square and path coefficient were obtained from PLS algorithm, while t-value generated from bootstrapping process. As previously explained, interpretation of $\mathrm{R}$-square value is similar with interpretation of conventional regression. This value shows goodness fit of independent variable in describing its dependent variable. Table VIII shows the value of R-square.

Path coefficient and t-value are commonly used to evaluate model structure, and particularly used to test the study hypotheses. Path coefficient has positive and negative values used to test whether two variables related as described in the hypotheses. Meanwhile, t-value was used to test significance of relation shown in path coefficient. The value of path coefficient, t-value, $\mathrm{p}$-value, and t-table with 0.05 significance 0.05 are shown in Table IX. Based on these data, it can be determined that nearly all hypotheses were accepted, except for relation between perceived control and attitude, which was insignificant. Generally, according to the results, learning behavior variables have positive relation significantly. However, it must pay attention during categorizing these variables. According to [28], different categorizing gave different results.

In the proposed inner model, there were two path that involved two mediation variables: (i) Path from perceived ease of use to attitude via mediation variable of perceived usefulness ( $\mathrm{PE} \rightarrow \mathrm{PU} \rightarrow \mathrm{AT}$ ); and (ii) path from perceived control to intention via mediation variable of attitude $(\mathrm{PC} \rightarrow \mathrm{AT} \rightarrow \mathrm{IT})$. Using Sobel equation, both mediation variables were checked to determine whether they were significant or not (indirect effect). The relation of indirect effect with Sobel equation using standard normal distribution is displayed in Fig. 4.

If $a$ and $s_{a}$ are path coefficient and standard error of relation between $\mathrm{X}$ and $\mathrm{Y}$, while $b$ and $s_{b}$ are path coefficient and standard error of relation between $\mathrm{Y}$ and $\mathrm{Z}$, then standard normal distribution $(\mathrm{z})$ of both relations is:

$z=\frac{a * b}{\sqrt{a^{2} * s_{b}^{2}+b^{2} * s_{a}^{2}}}$

TABLE VIII. R-SQUARE

\begin{tabular}{|l|l|}
\hline & R-Square \\
\hline Attitude & 0.505674 \\
\hline Enjoyment & 0.435945 \\
\hline Intensity & 0.424761 \\
\hline Intention & 0.565391 \\
\hline PC & 0.220707 \\
\hline PE & 0.084482 \\
\hline PU & 0.505752 \\
\hline Sk-Ch & \\
\hline
\end{tabular}

TABle IX. Path CoefFicient And T-Value

\begin{tabular}{|c|c|c|c|c|c|c|}
\hline & $\begin{array}{l}\text { Path } \\
\text { Coeffi } \\
\text { cient }\end{array}$ & $\begin{array}{l}\text { Stan } \\
\text { dard } \\
\text { Error }\end{array}$ & $\begin{array}{l}\text { t- } \\
\text { value }\end{array}$ & $\begin{array}{l}\text { p- } \\
\text { value }\end{array}$ & $\begin{array}{l}\text { t-table, } \\
\alpha=0.05 \\
d f=185\end{array}$ & Decision \\
\hline $\begin{array}{l}\text { Attitude -> } \\
\text { Intention }\end{array}$ & 0.633 & 0.137 & 4.628 & 0.000 & \multirow{12}{*}{1.653} & Supported \\
\hline $\begin{array}{l}\text { Enjoyment } \\
\text {-> Attitude }\end{array}$ & 0.239 & 0.099 & 2.424 & 0.008 & & Supported \\
\hline $\begin{array}{l}\text { Intention - } \\
>\text { Intensity }\end{array}$ & 0.652 & 0.088 & 7.431 & 0.000 & & Supported \\
\hline $\begin{array}{l}\text { PC -> } \\
\text { Attitude }\end{array}$ & 0.066 & 0.111 & 0.594 & 0.277 & & $\begin{array}{l}\text { Not } \\
\text { Support }\end{array}$ \\
\hline $\begin{array}{l}\text { PC -> } \\
\text { Intention }\end{array}$ & 0.227 & 0.127 & 1.792 & 0.037 & & Supported \\
\hline $\begin{array}{l}\text { PE -> } \\
\text { Attitude }\end{array}$ & 0.343 & 0.137 & 2.509 & 0.006 & & Supported \\
\hline PE -> PU & 0.654 & 0.060 & 10.942 & 0.000 & & Supported \\
\hline $\begin{array}{l}\text { PU -> } \\
\text { Attitude }\end{array}$ & 0.232 & 0.109 & 2.118 & 0.018 & & Supported \\
\hline $\begin{array}{l}\text { Sk-Ch -> } \\
\text { Enjoyment }\end{array}$ & 0.660 & 0.078 & 8.429 & 0.000 & & Supported \\
\hline $\begin{array}{l}\text { Sk-Ch -> } \\
\text { PC }\end{array}$ & 0.470 & 0.081 & 5.801 & 0.000 & & Supported \\
\hline $\begin{array}{l}\text { Sk-Ch -> } \\
\text { PE }\end{array}$ & 0.291 & 0.105 & 2.756 & 0.003 & & Supported \\
\hline $\begin{array}{l}\text { Sk-Ch -> } \\
\text { PU }\end{array}$ & 0.147 & 0.082 & 1.794 & 0.037 & & Supported \\
\hline
\end{tabular}

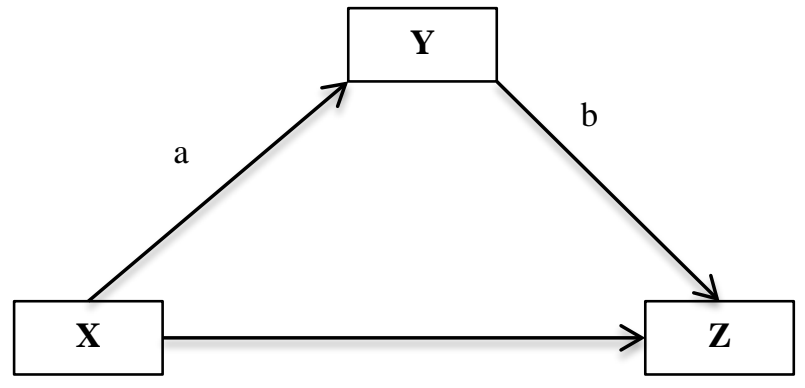

Fig. 4. Indirect effect.

Based on the data in Table IX, the value of standard normal distribution with Sobel test was obtained as shown in Table X.

By using 5\% significance, the relation of indirect effect $\mathrm{PE} \rightarrow \mathrm{PU} \rightarrow \mathrm{AT}$ was significant, while indirect effect $\mathrm{PC} \rightarrow \mathrm{AT} \rightarrow$ IT was not significant. This result was in line with values of path coefficient and t-value from relation PC $\rightarrow$ AT that was not significant. The results of testing the relationship between the learning behavior variable and the psychological experience variable are then used as the basis that the multicriteria attribute related to actual usage can be used to measure or predict psychological conditions in learning through e-learning.

TABLE X. PATH CoefFicient AND T-VAlue

\begin{tabular}{|l|l|l|l|}
\hline Path & $\mathbf{z}$ value & p-value, one tailed & Decision \\
\hline PE->PU->AT & 2.080 & 0.019 & Significant \\
\hline PC->AT->IT & 0.589 & 0.278 & Not significant \\
\hline
\end{tabular}




\section{CONCLUSION}

Investigation of relations among learning behavior as a multicriteria attribute, TAM, and flow experience as a representation of psychological experience was presented in this study. The main contribution of this research is to provide a way on how to measure the psychological experience of elearning naturally. Learning behavior when interacting with elearning becomes the main variable in determining attribute multicriteria. All variables illustrated in structure model showed positive relations, thus all causal relations proposed in the hypotheses were accepted. This result also provide indication that learning intensity as a representation of learning behavior could be used as a reference to identify user's behavior during interaction with e-learning. If this is combined with skill-challenge balance as an antecedent flow experience, it could create engagement between user and elearning system. However, these parameters have not been tested in real cases. This research is still limited to the relationship between variables that can be used as attributes to measure or predict the psychological learning experience. In the future research, this multicriteria attribute can be used as parameters for prediction and classification of flow experience. It can use several prediction methods such as machine learning, rough set, or rough-regression.

\section{ACKNOWLEDGMENT}

This research is funded by the Grant of Fundamental Research Scheme from the Ministry of Research, Technology, and Higher Education, Republic of Indonesia, 2020.

\section{REFERENCES}

[1] Manzoor, H.-L. Truong, and S. Dustdar, "Quality of Context: models and applications for context-aware systems in pervasive environments," Knowl. Eng. Rev., vol. 29, no. 2, pp. 154-170, Mar. 2014.

[2] G. Zhang and Z. Cheng, “A WWW-based learner's learning motivation detecting system,” 2003.

[3] C. Whitson and J. Consoli, "Flow Theory and Student Engagement," J. Cross-Disciplinary Perspect. Educ., vol. 2, no. 1, pp. 40-49, 2009.

[4] J. Nakamura and M. Csikszentmihalyi, "The concept of flow," The handbook of positive psychology. pp. 89-105, 2002.

[5] D. J. Shernoff and E. Rowe, "Measuring Flow in Educational Games and Gamified Learning Environments Increasing Engagement in Learning through Serious Educational Video Games Theoretical Foundation: Flow Experiences and Their Relationship to Learning,” pp. 2276-2281, 2012.

[6] M. Csikszentmihalyi, Flow: The Psychology of Optimal Experience. New York, NY: Harper and Row, 1990.

[7] $\mathrm{P}$. $\mathrm{Pu}$ and L. Chen, "A user-centric evaluation framework of recommender systems,” CEUR Workshop Proc., vol. 612, pp. 14-21, 2010.

[8] D. S. S. Sahid, L. E. Nugroho, and P. I. Santosa, "Modeling the Flow Experience for Personalized Context Aware E-learning,” in Proceedings of The 8th 2016 International Conference on Information Technology and Electrical Engineering, 2016, pp. 236-241.

[9] F. D. Davis, "Perceived usefulness, perceived ease of use, and user acceptance of information technology,” MIS Q., vol. 13, no. 319-339, 1989.

[10] D. A. Adams, R. R. Nelson, and P. A. Todd, "Perceived Usefulness, Ease of Use, and Usage of Information Technology,” MIS Q., vol. 16, no. 2, pp. 227-247, 1992.

[11] V. Venkatesh and F. D. Davis, "A Theoretical Extension of the Technology Acceptance Model: Four Longitudinal Field Studies,” Manage. Sci., vol. 46, no. 2, pp. 186-204, 2000.

[12] W. W. Chin and P. A. Todd, "On the Use, Usefulness, and Ease of Use of Structural Equation Modeling in MIS Research: A Note of Caution,” MIS Q., vol. 19, no. 2, pp. 237-246, 1995.

[13] I. Ajzen, Attitudes, Personality and Behavior, 2nd ed. Open University Press, 2005.

[14] R. M. Gagne, L. J. Briggs, and W. W. Wager, Principles of Instructional Design. Orlando: Ted Buchholz, 1992.

[15] A. H. Eagly and S. Chaiken, The psychology of attitudes. Fort Worth, Tex. Harcourt Brace Jovanovich College, 1993.

[16] I. Ajzen and T. J. Madden, "Prediction of Goal-Directed Behavior: Attitudes, Intentions, and Perceived Behavioral Control,” J. Exp. Soc. Psychol., vol. 22, pp. 453-474, 1986.

[17] N. S. Endler, R. L. Speer, J. M. Johnson, and G. L. Flett, "Controllability, coping, efficacy, and distress," Eur. J. Pers., vol. 14, no. 3, pp. 245-264, 2000.

[18] E. Skinner and T. Greene, "Perceived Control: Engagement, Coping, and Development,” in 21st Century Education: A Reference Handbook, SAGE Publications Ltd, 2007, pp. 91-106.

[19] K. Bodey and D. Grace, "Examining Self-Monitoring, Perceived Control, Self-Efficacy and Machiavellianism in the Context of Complaint Behaviour,” Mark. Accountabilities Responsib., 2004.

[20] M. Cocea and S. Weibelzahl, Log file analysis for disengagement detection in e-Learning environments, vol. 19, no. 4. 2009.

[21] G. B. Moneta, “On the Measurement and Conceptualization of Flow.”

[22] L. Liao, "A Flow Theory Perspective on Learner Motivation and Behavior in Distance Education,” Distance Educ., vol. 27, no. 1, pp. 4562, 2006.

[23] J. A. Fredricks, P. C. Blumenfeld, and A. H. Paris, "School Engagement: Potential of the Concept, State of the Evidence,” Rev. Educ. Res., vol. 74, no. 1, pp. 59-109, 2004.

[24] H. M. Marks, "Student Engagement in Instructional Activity: Patterns in the Elementary, Middle, and High School Years,” Am. Educ. Res. J., vol. 37, no. 1, pp. 153-184, 2000.

[25] F. M. Newmann and G. G. Wehlage, "Five Standards of Authentic Instruction,” Educ. Leadersh., vol. 50, no. 7, pp. 8-12, 1993.

[26] D. J. Shernoff, M. Csikszentmihalyi, B. Schneider, and E. S. Shernoff, "Student Engagement in High School Classrooms from the Perspective of Flow Theory,” Sch. Psychol. Q., vol. 18, no. 2, pp. 158-176, 2003.

[27] M. C. Lee, “Explaining and predicting users' continuance intention toward e-learning: An extension of the expectation-confirmation model,” Comput. Educ., vol. 54, no. 2, pp. 506-516, 2010.

[28] D. S. S. Sahid, R. Efendi, E.H. Putra and M. Wahyudi, "Categorizing Attributes in Identifying Learning Style Using Rough Set Theory," (IJACSA) International Journal of Advanced Computer Science and Applications, vol. 11, no. 1, 2020, pp. 292-298. 